\section{Den socialdemokratiske idé}

Claus Bryld: Den socialdemokratiske idéarv. Roskilde Universitetsforlag, 2004, 340 sider, kr. 298,-

Den socialdemokratiske idéarv er en antologi bestående af artikler skrevet af Claus Bryld, professor i moderne historie ved Roskilde Universitetscenter. Artiklerne omhandler den danske arbejderbevægelses historie i perioden frem til 2. verdenskrig med fokus på værdier og ideologiske grundholdninger.

Bogen er delt op i fire hoveddele. Den første del omhandler Socialdemokratiets forhold til den internationale arbejderbevægelse i perioden indtil 1. verdenskrig. Den andel del omhandler Socialdemokratiets ideologiske grundholdninger $\mathrm{i}$ tiden frem til 2. verdenskrig. Denne del indeholder også en artikel, der beskriver samarbejdet imellem Socialdemokratiet og det Radikale Venstre, og de ideologiske ligheder, der gjorde det frugtbare samarbejde mellem de to partier muligt. Den tredje del vurderer arbejderbevægelsens betydning for opbygningen af velfærdssamfundet. Det er Brylds opfattelse, at arbejderbevægelsens organisering og styrke var af afgørende betydning for opbygningen af de skandinaviske velfærdsstater. Dette er et synspunkt, som i dag ikke er så fremtrædende $i$ den offentlige debat, der til gengæld ofte er præget af opfattelser, der på mere eller mindre fantasifuld vis for- søger at forklare velfærdssamfundets fremkomst med kristendommen.

Den fjerde del indeholder historiemetodologiske diskussioner, herunder en diskussion af reformismebegrebet, som specielt i den venstreorienterede historieskrivning har haft status af skældsord.

Bryld anfører, at det aldrig var den dybe forståelse af Marx' skrifter, der prægede den danske arbejderbevægelse. Den gængse ideologi var ofte præget af darwinistiske idéer, og historieopfattelsen var præget af en meget generel optimisme. Den danske arbejderbevægelses forestilling om overgangen til det socialistiske idealsamfund beskriver Bryld som gradualisme. Man ønskede ganske vist en samfundsomvæltning, men der var bred enighed om, at en sådan kunne gennemføres i etaper og vha. parlamentariske midler. Denne holdning var næsten enerådende i perioden frem til den russiske revolution. Det var kun få og små grupperinger, der havde en anden holdning, og disse grupper blev hurtigt udsondret af Socialdemokratiet og forsvandt uden at efterlade sig varige spor.

I artiklen om de socialdemokratiske grundværdier leder man forgæves efter en storslået socialdemokratisk samfundsvision. Dette skyldes næppe, at Bryld ikke har forsket nok i sit emne, men snarere at der kun i begrænset grad blev udarbejdet konkrete planer for en alternativ samfundsorden.

I et afsluttende kapitel skriver 
Bryld, at formålet med bogen også er at animere til udviklingen af en ny politisk vision som alternativ til de højreorienterede politiske vinde, der for tiden er dominerende i dansk politik. Han har dog ikke selv noget bud på en ny vision som alternativ til den borgerlige regerings politik. Man kan jo også spørge, om venstrefløjens problem virkelig er fraværet af en ny samfundsvision, eller om det snarere er, at vælgerne tvivler på at venstrefløjen kan magte nogle velkendte samfundsproblemer, f.eks. indenfor integrationsområdet.

Bogens stof er spændende, men Brylds stil kan forekomme en smule snakkende. Da der er tale om artikler, som delvis omhandler det samme emne, er der også en del gentagelser. Imidlertid vil artiklerne bestemt være interessante for den, der er interesseret $\mathrm{i}$ arbejderbevægelsens historie, og som ikke har det store forhåndskendskab til området.

Michael Jeppesen

\section{Skolastisk transcendentalfilosofi?}

Hannes Möble: Der Tractatus de Transcendentibus des Franciscus de Mayronis, Peeters 2004, 188 sider, € 40,-

Franciscus de Mayronis († ca. 1328) var blandt de studerende, som hørte Duns Scotus (ca. 1265-1308) i Paris i de første år af det fjortende århundrede. Duns Scotus artikulerede en ny metafysikforståelse, som dannede skole. Den scotistiske bevægelse var en meget udbredt filosofisk-teologisk retning $i$ den sene middelalder. Selv efter den moderne videnskabsforståelses gennembrud formåede scotismen at bevare sin integritet. I det syttende århundrede opnåede den sågar en ny blomstringstid, men var dog ligesom epokens andre skolastiske retninger så isoleret $\mathrm{i}$ forhold til den nye tids nye filosofi, at den nærmest helt og aldeles er undsluppet vor moderne filosofihistoriske bevidsthed. Blandt Duns Scotus' daværende elever var Franciscus de Mayronis en af de mest markante og virkningshistorisk vigtigste. En del af hans værker blev trykt og udgivet efter bogtrykkerkunstens opkomst i renæssancen, en anden del er kun overleveret $i$ middelalderlige afskrifter. Dertil hører det foreliggende skrift, som nu foreligger i en tekstkritisk, latinsk udgave, forsynet med en fyldig introduktion af udgiveren, Hannes Möhle, som tidligere har leveret bidrag til udforskningen af forskellige sider af Duns Scotus' tænkning.

Skriftet tager et emne op, som er af stor betydning for den scotistiske forståelse af metafysikken, transcendentalelæren. Duns Scotus kaldte metafysikken for den 'transcenderende videnskab', ikke fordi den handler om det transcendente qua det hinsides, men fordi den tager udgangspunkt $i$ den type begreber, som overskrider, transcenderer, alle andre, mere specielle begreber og 